Gut, 1972, 13, 871-873

\title{
Changes in glucose tolerance and serum insulin following partial gastrectomy and intestinal resection
}

\author{
S. WAPNICK ${ }^{1}$ AND J. J. JONES \\ From the Godfrey Huggins School of Medicine, Salisbury, Rhodesia
}

SUMMARY Partial gastrectomy and intestinal resection significantly impaired glucose tolerance $(P<0.05)$ and significantly decreased the release of insulin by intravenous glucose $(P<0.05)$ or a meal of minced beef $(P<0.01)$. There was a significantly greater release of insulin one hour after oral glucose in the gastrectomy patients $(\mathrm{P}<0.05)$.

It is clear that the absorption of glucose releases alimentary insulinotrophic factors (Perley and Kipnis, 1967; Marks and Samols, 1970; Karamanos, Butterfield, Asmal, Cox, and Whichelow, 1971), but there is no general agreement as to which of many possible humoral agents does in fact cause the secretion of insulin. In 1965, Samols, Marri, and Marks proposed that enteroglucagon was responsible but it is no longer in favour (Unger, 1971): secretin (Chisholm, Young, and Lazarus, 1969; Kraegen, Chisholm, Young, and Lazarus, 1970) or some as yet unidentified factor (Unger and Eisentraut, 1969) is now preferred. The effect of protein is yet more controversial: whereas Marks and Samols (1970) consider that the insulinotrophic effect of an exclusively protein meal can be explained by the concomitant slight increase in plasma amino acids, Dupré, Curtis, Unger, Waddell, and Beck (1969) point out that a far greater insulin secretion is produced when the amino acid, arginine, is absorbed from the duodenum than when it is injected intravenously.

The present study is to determine what changes occur in the secretion of insulin produced by oral and intravenous glucose or by a meal of minced beef in patients after partial gastrectomy or intestinal resection, and whether these changes can be explained by alterations in the release of the alirientary insulinotrophic agents.

\section{Subjects and Methods}

The healthy contrast group comprised 50 male cleaners at Harare Hospital who had a social and

${ }^{1}$ Present address: Department of Surgery, Ichilov Hospital, Tel Aviv Israel.

Received for publication 21 August 1972. economic background similar to the patients'. Ten patients had a Polya gastrectomy and 10 had a partial resection of 2 to $5 \mathrm{~m}$ of small intestine. ${ }^{1}$ Four or five weeks after operation they were given an oral $50 \mathrm{~g}$ glucose tolerance test, an intravenous $25 \mathrm{~g}$ glucose tolerance test, and blood glucose and serum insulin levels were measured after a meal of minced beef $(500 \mathrm{~g})$. Blood glucose was determined by the glucose oxidase method (Boehringer Mannheim) and serum insulin by radioimmune assay (Hales and Randle, 1963).

\section{Results}

The table and the chart show the fasting concentrations and the changes in blood glucose and insulin during the oral and intravenous glucose tolerance tests and after a meal of minced beef. The significance of the differences between the patients and the contrast group was tested by Wilcoxon's method.

ORAL GLUCOSE TOLERANCE

There was a significantly $(\mathrm{P}<0.05)$ greater rise in blood glucose one hour and two hours after oral glucose in both groups of patients and a significantly $(P<0.05)$ greater rise in insulin one hour after oral glucose in the gastrectomy patients.

INTRAVENOUS GLUCOSE TOLERANCE

There was a significantly $(P<0.05)$ smaller rise in

'The resections were performed to remove gangrenous bowel due
to adhesions in one patient and ileosigmoid knotting (volvulus) in
nine. In all cases a distal resection had been performed and in five the
ileocaecal valve had been bypassed or removed. Five patients had had
a moderate resection of 1 to 3 m of the small intestine. In the remaining
five patients $4 \cdot 1$ to $5 \mathrm{~m}$ of gangrenous bowel was removed. The length
of the residual jejunum measured at the time of operation of those
patients who had had a more major resection was 152 to $180 \mathrm{~cm}$. 871 


\begin{tabular}{|c|c|c|c|c|c|c|c|c|}
\hline & \multicolumn{2}{|c|}{ Healthy Contrast Group } & \multicolumn{3}{|c|}{ Partial Gastrectomy Patients } & \multicolumn{3}{|c|}{ Intestinal Resection Patients } \\
\hline & Median & $\begin{array}{l}\text { 10th \& 90th } \\
\text { Percentiles }\end{array}$ & Median & Range & $P<$ & Median & Range & $P<$ \\
\hline $\begin{array}{l}\text { Fasting glucose }(\mathrm{mg} / 100 \mathrm{ml}) \\
\text { Fasting insulin }(\mu \text {-unit } / \mathrm{ml})\end{array}$ & $\begin{array}{l}68 \\
15\end{array}$ & $\begin{array}{r}53 \text { to } 82 \\
5 \text { to } 26\end{array}$ & $\begin{array}{l}80 \\
19\end{array}$ & $\begin{array}{r}61 \text { to } 94 \\
6 \text { to } 27\end{array}$ & & $\begin{array}{l}70 \\
15\end{array}$ & $\begin{array}{r}50 \text { to } 90 \\
5 \text { to } 26\end{array}$ & \\
\hline $\begin{array}{l}\text { Oral glucose at one hour } \\
\text { Change in glucose } \\
\text { Change in insulin }\end{array}$ & $\begin{array}{r}9 \\
15\end{array}$ & $\begin{array}{r}-8 \text { to } 45 \\
1 \text { to } 42\end{array}$ & $\begin{array}{l}44 \\
28\end{array}$ & $\begin{array}{r}-21 \text { to } 123 \\
6 \text { to } 76\end{array}$ & $\begin{array}{l}0.05 \\
0.05\end{array}$ & $\begin{array}{l}30 \\
16\end{array}$ & $\begin{array}{r}-10 \text { to } 90 \\
4 \text { to } 56\end{array}$ & 0.05 \\
\hline $\begin{array}{l}\text { Oral glucose at two hours } \\
\text { Change in glucose } \\
\text { Change in insulin }\end{array}$ & $\begin{array}{l}1 \\
5\end{array}$ & $\begin{array}{r}-16 \text { to } 28 \\
1 \text { to } 19\end{array}$ & $\begin{array}{r}14 \\
5\end{array}$ & $\begin{array}{r}-25 \text { to } 62 \\
-4 \text { to } 11\end{array}$ & 0.05 & $\begin{array}{l}8 \\
6\end{array}$ & $\begin{array}{r}-20 \text { to } 80 \\
3 \text { to } 14\end{array}$ & 0.05 \\
\hline $\begin{array}{l}\text { Intravenous glucose at five min } \\
\text { Change in glucose } \\
\text { Change in insulin }\end{array}$ & $\begin{array}{r}156^{1} \\
54^{1}\end{array}$ & $\begin{array}{r}110 \text { to } 230 \\
12 \text { to } 250\end{array}$ & $\begin{array}{r}152 \\
20\end{array}$ & $\begin{array}{r}88 \text { to } 188 \\
4 \text { to } 64\end{array}$ & 0.05 & $\begin{array}{r}153 \\
21\end{array}$ & $\begin{array}{r}120 \text { to } 210 \\
4 \text { to } 69\end{array}$ & 0.05 \\
\hline $\begin{array}{l}\text { Beef at one hour } \\
\text { Change in glucose } \\
\text { Change in insulin }\end{array}$ & $\begin{array}{r}-6^{1} \\
10^{1}\end{array}$ & $\begin{array}{c}-20 \text { to } 6 \\
0 \text { to } 18\end{array}$ & $\begin{array}{r}2 \\
1.5\end{array}$ & $\begin{array}{r}-50 \text { to } 6 \\
-2 \text { to } 6\end{array}$ & $\begin{array}{l}0.05 \\
0.01\end{array}$ & $\begin{array}{c}-4 \\
2 \cdot 5\end{array}$ & $\begin{array}{r}-24 \text { to } 18 \\
-1 \text { to } 7\end{array}$ & 0.01 \\
\hline $\begin{array}{l}\text { Beef at two hours } \\
\text { Change in glucose } \\
\text { Change in insulin }\end{array}$ & $\begin{array}{l}0^{1} \\
6^{1}\end{array}$ & $\begin{array}{r}-9 \text { to } 12 \\
1 \text { to } 20\end{array}$ & $\begin{array}{l}6 \\
8\end{array}$ & $\begin{array}{r}-24 \text { to } 10 \\
-3 \text { to } 25\end{array}$ & 0.05 & $\begin{array}{r}-6 \\
2\end{array}$ & $\begin{array}{r}-16 \text { to } 16 \\
-1 \text { to } 6\end{array}$ & 0.01 \\
\hline
\end{tabular}

Table Fasting blood glucose and insulin and the changes occurring during the oral and intravenous glucose tolerance tests and after a meal of minced beef

${ }^{1}$ Measured in 20 patients.

serum insulin in both groups of patients five minutes after intravenous glucose.

\section{MINCED BEEF}

There was a significantly $(\mathrm{P}<0.01)$ smaller rise in serum insulin in both groups of patients one hour after a meal of minced beef and also in the intestinal
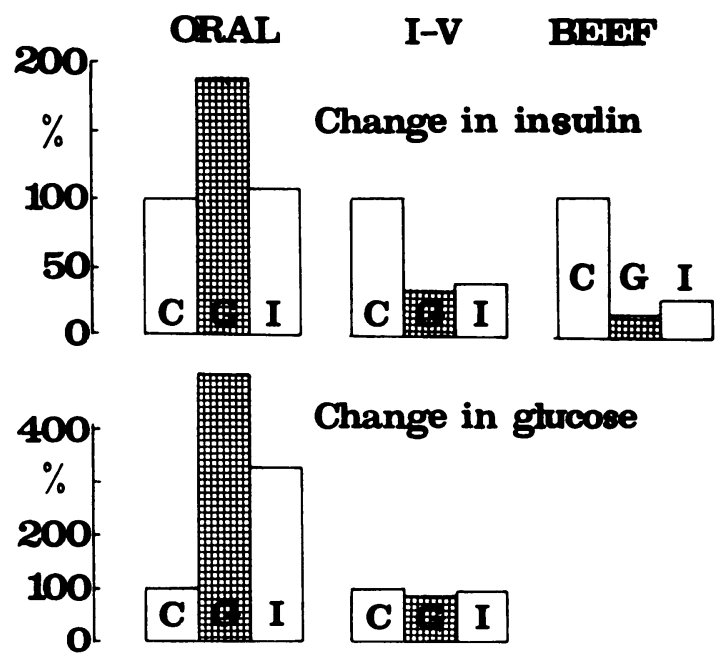

Fig. The chart shows the changes in serum insulin and blood glucose in the two groups of patients one hour after oral glucose, five minutes after intravenous glucose, and one hour after a meal of minced beef expressed as a percentage of the corresponding changes in the healthy contrast group $(C)$. G signifies gastrectomy patients and I signifies intestinal resection patients. resection patients two hours after the meal. The rise in blood glucose was significantly $(P<0.05)$ higher in the gastrectomy patients.

\section{Discussion}

Secretion of gastrin, secretin, and pancreozymincholecystokinin are reduced by partial gastrectomy (Davenport, 1966) so that the significantly greater insulin secretion after oral glucose in gastrectomy patients must be due to some other jejunal insulinotrophic factor; it cannot simply be the result of more rapid glucose absorption from the jejunum because glucose injected intravenously produced no greater response despite a considerably greater rise in blood glucose (Holdsworth, Turner, and McIntyre, 1969; Shultz, Neelson, Nilsen, Lebovitz, and Durham, 1971). After intestinal resection, there was no change in the release of insulin by oral glucose showing that the insulinotrophic factors released by glucose are mainly confined to the upper part of the small intestine. Preliminary experiments in which glucose was introduced into recirculating loops of the small intestine in anaesthetized rabbits (Wapnick, 1972) also suggest that the insulinotrophic action of glucose is greater in the upper jejunum than in the terminal ileum.

In contrast to glucose, a meal of minced beef was found to be significantly less effective in releasing insulin after partial gastrectomy or intestinal resection which indicates that the insulinotrophic factors from the stomach and from the whole of the small intestine, eg, enteroglucagon (Kenny and Say, 1962) are released during the absorption of protein, and 
that alimentary insulinotrophism is dependent on the type of food absorbed (Unger and Eisentraut, 1969). The change in plasma amino acids after the meat meal was not measured and it is possible that a decrease in the exocrine proteolytic gastric and pancreatic secretion delayed protein digestion and accounts for diminished insulin secretion in the postgastrectomy and intestinal resection patients.

Insulin secretion following intravenous glucose was significantly reduced both by partial gastrectomy (Shultz et al, 1971) and by intestinal resection. This may be the result of a decrease in the fasting release of the alimentary insulinotrophic agents (including gastrin, secretin, pancreozymin-cholecystokinin, and enteroglucagon) since each one of them has been shown to enhance the insulinotrophic action of intravenous glucose (Samols et al, 1965; Dupré, Curtis, and Beck, 1967; Dupré et al, 1969), possibly by increasing pancreatic blood flow (Harper, 1967). Alternatively, the impaired response to intravenous glucose may be the result of incidental operative interference with the nerve or blood supply to the pancreas.

Finally, both the partial gastrectomy and intestinal resection patients showed an impaired oral glucose tolerance with significantly higher blood glucose concentrations at two hours, despite normal insulin concentrations. It seems possible that the alimentary factors may be concerned not only with the release of insulin, but also with its peripheral action on the tissues.

We wish to thank Mr E. Kanengoni for assaying the serum insulin.
References

Chisholm, D. J., Young, J. D., and Lazarus, L. (1969). The gastrointestinal stimulus to insulin release. I. Secretin. J. clin. Invest., 48, 1453-1460.

Davenport, H. W. (1966). Physiology of the Digestive Tract, 2nd ed. Year Book Medical Publishers, Chicago.

Dupre, J., Curtis, J. D., and Beck, J. C. (1967). Insulinotropic action of secretin. Brit. med. J., 3, 560 .

Dupré, J., Curtis, J. D., Unger, R. H., Waddell, R. W., and Beck, J. C. (1969). Effects of secretin, pancreozymin, or gastrin on the response of the endocrine pancreas to administration of glucose or arginine in man. J. clin. Invest., 48, 745-757.

Hales, C. N., and Randle, P. J. (1963). Immunoassay of insulin with insulin antibody precipitate. Lancet, 1, 200.

Harper, A. A. (1967). Hormonal control of pancreatic secretion. In Handbook of Physiology, Sect. 6, Vol. II, edited by M. B. Visscher, A. B. Hastings, J. R. Pappenheimer, and H. Rahn, pp. 969-995. Williams and Wilkins, Baltimore.

Holdsworth, C. D., Turner, D., and McIntyre, N. (1969). Pathophysiology of post-gastrectomy hypoglycaemia. Brit. med. J., 4, 257-259.

Karamanos, B., Butterfield, W. J. H., Asmal, A. C., Cox, B. D., and Whichelow, M. J. (1971). The pattern of early insulin response to oral glucose. Postgrad. med. J., June Suppl., 440-443.

Kenny, A. J., and Say, R. R. (1962). Glucagon-like activity extractable from the gastro-intestinal tract of man and other animals. J. Endocr., 25, 1-7.

Kraegen, E. W., Chisholm, D. J., Young, J. D., and Lazarus, L. (1969). Theg astro-intestinal stimulus to insulin release. II. A dual action of secretin. J. clin. Invest., 49, 524-529.

Marks, V., and Samols, E. (1970). Intestinal factors in insulin secretion regulation. Advanc. metab. Dis., 4, 1-38.

Perley, M. J., and Kipnis, D. M. (1967). Plasma insulin response to oral and intravenous glucose: studies in normal and diabetic subjects. J. clin. Invest., 46, 1954-1962.

Samols, E., Marri, G., and Marks, V. (1965). Promotion of insulin secretion by glucagon. Lancet, 2, 415-416.

Shultz, K. T., Neelson, F. A., Nilsen, L. B., Lebovitz, H. E., and Durham, N. C. (1971). Mechanism of postgastrectomy hypoglycemia. Arch. intern. Med., 128, 240-246.

Unger, R. H. (1971). Glucagon physiology and pathophysiology. New Engl. med. J., 285, 443-448.

Unger, R. H., and Eisentraut, A. M. (1969). Entero-insular axis. Arch. intern. Med., 123, 261-266.

Wapnick, S. (1972). The small intestine-the effect of its removal. Medical Faculty Research Lecture, University of Rhodesia, Salisbury. 